\title{
IDENTIFICATION OF OXYSPIRURA MANSONI (SPIRURIDA: THELAZIIDAE) IN A FREE-RANGE HEN (GALLUS GALLUS DOMESTICUS) AND ITS INTERMEDIATE HOST, SURINAM COCKROACH (PYCNOSCELUS SURINAMENSIS) IN MONTERREY, NUEVO LEON, MEXICO
}

\author{
FrANCISCO A. SANTOYO-DE-ESTÉFANO, ${ }^{1}$ ROSENDO R. ESPINOZA-LEIJA, ${ }^{1}$ \\ JUAN J. ZÁRATE-RAMOS ${ }^{1}$ \& XóCHITL HERNÁNDEZ-VELASCO ${ }^{2}$ \\ ${ }^{1}$ Facultad de Medicina Veterinaria y Zootecnia de la Universidad Autónoma de Nuevo León. Francisco \\ Villa s/n, Col. Ex-Hacienda El Canadá, Escobedo 66050, Monterrey, N. L., México. \\ ${ }^{2}$ Departamento de Medicina y Zootecnia de Aves, Facultad de Medicina Veterinaria y Zootecnia, \\ Universidad Nacional Autónoma de México. Av. Universidad 3000, C. U., UNAM, 04510, \\ México D. F., México. \\ ${ }^{2}$ Corresponding author: <xochilt_h@yahoo.com>
}

Santoyo-De-Estéfano, F. A., Espinoza-Leija, R. R., Zarate-Ramos, J. J. \& Hernández-Velasco, X. 2014. Identification of Oxyspirura mansoni (Spirurida: Thelaziidae) in a free-range hen (Gallus gallus domesticus) and its intermediate host, Surinam cockroach (Pycnoscelus surinamensis) in Monterrey, Nuevo Leon, Mexico. Acta Zoológica Mexicana (n.s.), 30(1): 106-113.

ABSTRACT. The current report addresses the finding of ocular filariosis in a domestic adult hen, raised in a backyard, in a community near La Silla River, south Nuevo Leon, in Mexico. The hen was submitted to a veterinary practice due to weakness and diarrhea. During necropsy, three nematodes were found underneath the nictitating membranes in both of the bird's eyes. The nematodes were identified as Oxyspirura mansoni. The diagnostic was confirmed when the intermediate host of $O$. mansoni, the Surinam cockroach (Pycnoscelus surinamensis), was found in the hen's living environment.

Key words: Oxyspirura mansoni, bird eyeworm, Pycnoscelus surinamensis, Surinam cockroach, free roaming hen, Gallus gallus domesticus.

Santoyo-De-Estéfano, F. A., Espinoza-Leija, R. R., Zárate-Ramos, J. J. \& Hernández-Velasco, X. 2014. Identificación de Oxyspirura mansoni (Spirurida: Thelaziidae) en una gallina de traspatio (Gallus gallus domesticus) y de su huésped intermediario, la cucaracha de Surinam (Pycnoscelus surinamensis), en Monterrey, Nuevo León, México. Acta Zoológica Mexicana (n.s.), 30(1): 106-113.

RESUMEN. El presente trabajo reporta el hallazgo de una filariosis ocular en una gallina doméstica adulta, criada en traspatio en una comunidad cercana al río La silla, al sur de Nuevo León, México. La gallina fue remitida para una práctica de veterinaria debido a que presentaba debilidad y diarrea. A la

Recibido: 29/04/2013; aceptado: 23/09/2013. 
necropsia, fueron encontrados tres nematodos debajo de la membrana nictitante en ambos ojos. Los nematodos fueron identificados como Oxyspirura mansoni. El diagnóstico fue confirmado cuando el huésped intermediario de O. mansoni, la cucaracha de Surinam (Pycnoscelus surinamensis), fue hallado en el lugar donde habitaba la gallina.

Palabras clave: Oxyspirura mansoni, Pycnoscelus surinamensis, cucaracha de Surinam, Gallus gallus domesticus.

\section{INTRODUCTION}

Two types of Spirurida nematodes are identified as parasites of the eye in avian species, Oxyspirura and Thelazia. The genus Oxyspirura includes approximately 70 species, from which $O$. mansoni, $O$. petrowi, and $O$. pusillae have been reported in wild and domestic birds in North America (Yazwinsk \& Tucker 2008). Oxyspirura mansoni, the eyeworm of poultry, is a nematode widely distributed in many tropical and subtropical countries (Islam et al. 1995; Lee et al. 2006; De Chirinos et al. 2009). $O$. mansoni has been reported in a wide variety of avian orders: Anseriformes, Falconiformes, Galliformes, Columbiformes, and Passeriformes (Ransom 1904; Schwabe 1951; Chirinos \& Godoy 1999; Abrams et al. 2002; Vellayan et al. 2012).

In Mexico, Oxyspirura mansoni has been reported in the Golden-cheeked Woodpecker (Centurus chrysogenus), the Northern Harrier (Circus hudsonius) and the Fulvous owl (Strix fulvescens) (Rodríguez-Tovar et al. 2008).

\section{MATERIAL AND METHODS}

A domestic adult hen (Gallus gallus domesticus) from a rural community in the La Silla river valley, south Nuevo Leon state, was submitted to the College of Veterinary Medicine and Zootechny, at the Nuevo Leon Autonomous University. The hen had been showing signs of clinical gastrointestinal distress and prostration. Upon physical examination, the bird was found depressed and to have reduced body weight. After the bird was euthanized according to Bermudez \& Stewart-Brown (2008) for further necropsy, three nematodes were found underneath the nictitating membranes, two in the left eye and one in the right eye (Fig. 1). Other nematodes were found on the cecal mucosa. The parasites were collected and preserved in 70\% ethanol, decolored with lactophenol (Doster \& Goater 1997), and submitted to the Parasitology Laboratory of the Avian Medicine Department to be identified. No macroscopic findings associated with other diseases were observed.

\section{RESULTS AND DISCUSSION}

The three nematodes collected were identified as two females and one male. They had a small and round body size, covered with a thin white cuticle. The anterior end was rounded, and the posterior end was sharp. The pharynx was short, broader in its posterior end, connecting to a club-shaped esophagus (Fig. 2). 


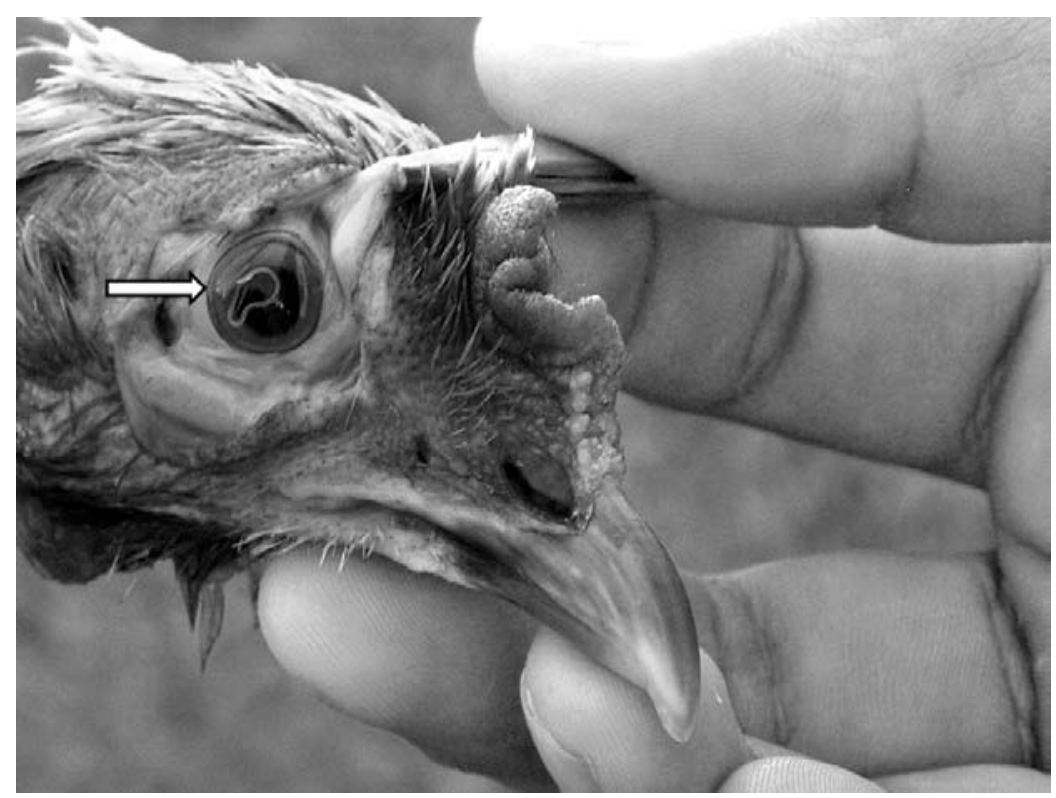

Figure 1. Oxyspirura mansoni found on the cornea. The parasite was intentionally placed on the iris of the hen (Gallus gallus domesticus) to facilitate its visualization.

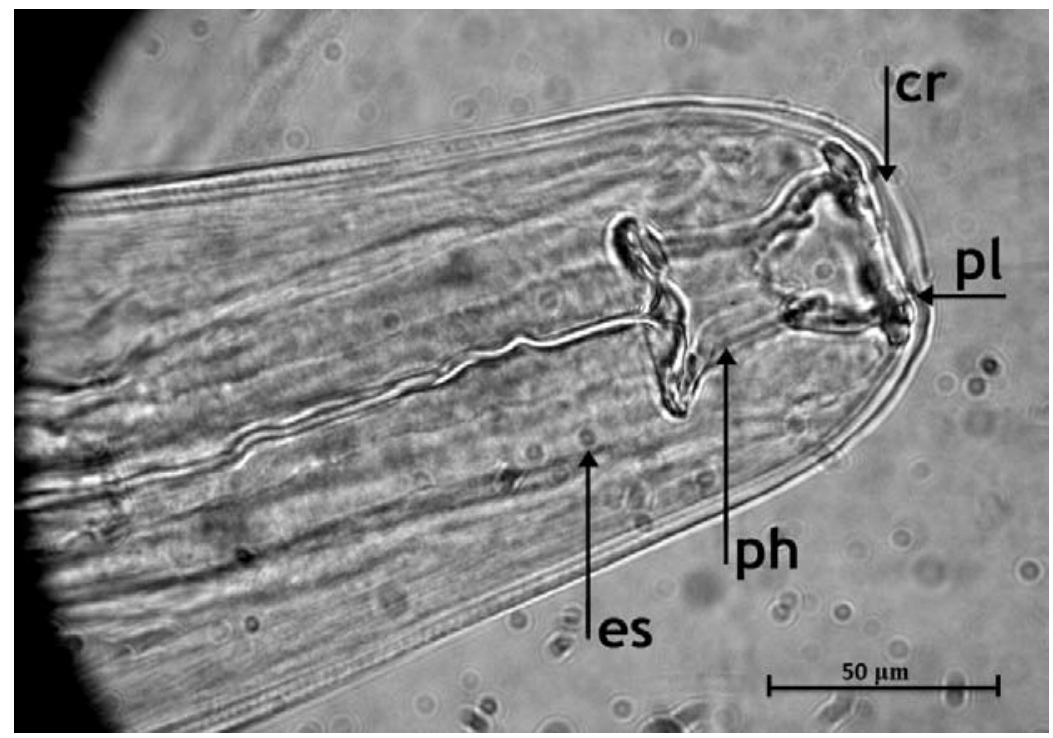

Figure 2. Oxyspirura mansoni. Dorsal view of anterior end of a maleshowing cuticular ring (cr); esophagus (es); pharynx ( $p h)$, and lateral papilla $(l p)$. 
The measurements of the male's body were $11.2 \mathrm{~mm}$ long by $275 \mu \mathrm{m}$ wide. The male's body length was shorter than the female's length, and based on visible observations, the testicles occupied a fourth of its body length. Its posterior end is sharp and concave, with two unequal spicules measuring $348 \mu \mathrm{m}$ by $9 \mu \mathrm{m}$, and $212 \mu \mathrm{m}$ by $27 \mu \mathrm{m}$, respectively (Fig. 3).

The measurements of the females' bodies were $12.7 \mathrm{~mm}$ long by $0.41 \mathrm{~mm}$ wide, and $15.4 \mathrm{~mm}$ long by $0.425 \mathrm{~mm}$ wide, respectively. The females were characterized by having two uteri that occupied the posterior portion of their bodies. In this particular case, embryonated eggs were found in the females' reproductive system. The eggs had a characteristic oval shape, with a measured size of $55 \mu \mathrm{m} \times 40 \mu \mathrm{m}$ (fig. 4). Overall, the morphology of the parasites and the eggs was in agreement with previous descriptions and published reports of nematodes from the Order Spirurida, Family Thelaziidae, Genus Oxyspirura, species mansoni (Ransom 1904; Soulsby 1983). The nematodes found in the ceca were identified as Heterakis gallinarum (Soulsby 1983; Yazwinsk \& Tucker 2008). Weakness and diarrhea were associated to the presence of Heterakis.

The route of infection in the hen was related with the presence of the burrowing cockroach. This insect belongs to the Genus Pycnoscelus, and is the intermediate natural host of Oxyspirura mansoni. The cockroach was found in cracks, crevices, and

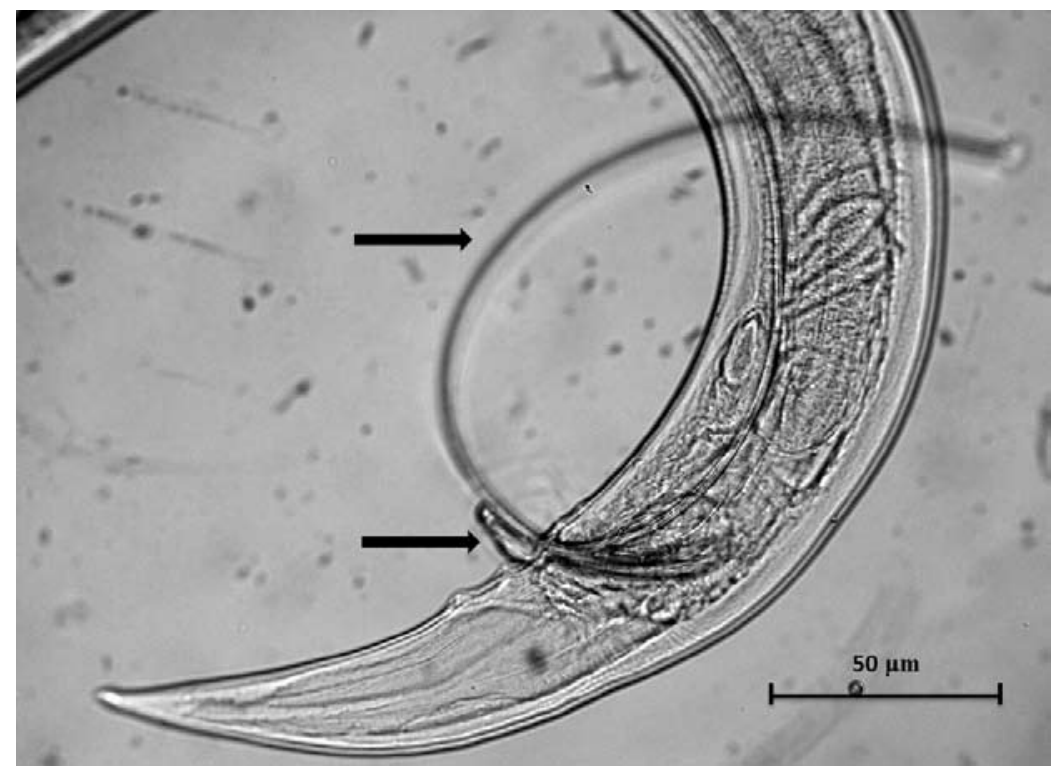

Figure 3. Oxyspirura mansoni. Lateral view of the posterior end of a male Oxyspirura mansoni showing its unequal spicules (arrows). 


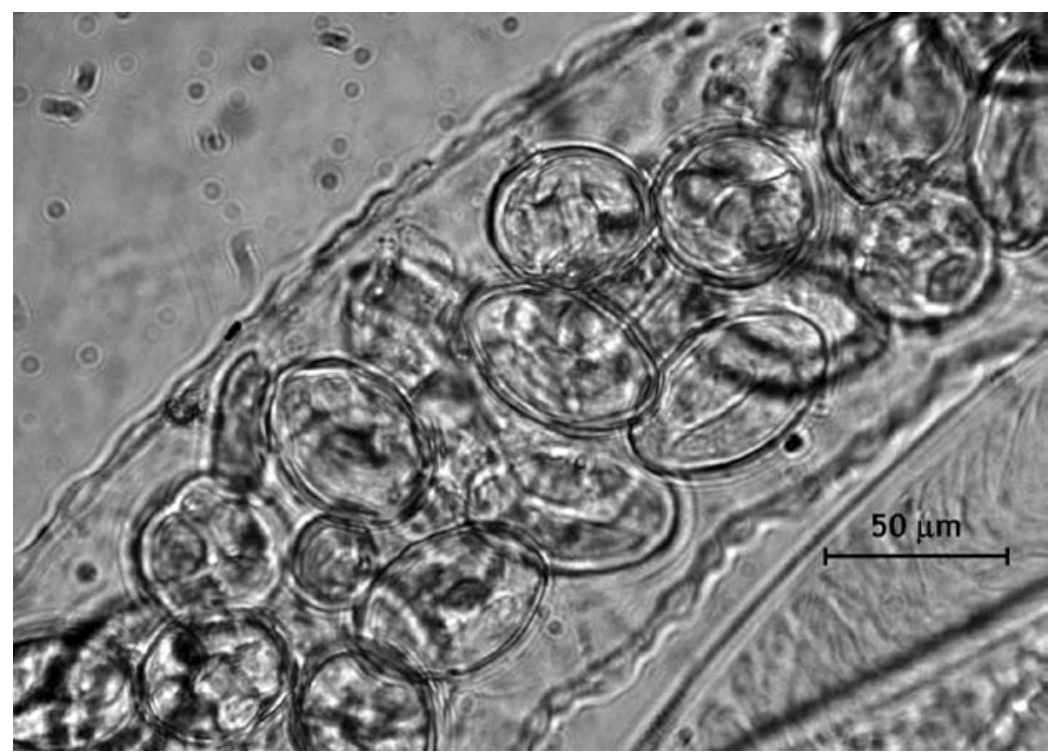

Figure 4. Embryonated eggs inside the uterus of Oxyspirura mansoni.

underneath debris on the premises. The insects were identified as Pycnoscelussurina mensis(Fig. 5) and Neostylopygar hombifolia. Pycnoscelus surinamensis, Order Orthoptera, Suborder Blattaria, Family Blattidae, is known to be the only intermediate host of $O$. mansoni and is widely distributed in the American continent (Jacobs et al. 2003; Malgalhaes \& Caldas 2004).

Oxyspirura mansoni has a digenetic biological cycle in which numerous wild and domestic avian species may serve as the definitive host. The intermediate host is the cockroach Pycnoscelus surinamensis (Doster \& Goater 1997). The birds become infested through the ingestion of the cockroach that was infected with the parasite (Chirinos \& Godoy 1999; Lee et al. 2006). Once in the digestive tract of the host, the larvae are released and migrate from the esophagus to the eye through the nasolachrymal ducts. The larvae then become sexually mature, and their eggs move through the same ducts to the pharynx. The eggs are then swallowed by the bird, transported through the digestive tract, and eliminated through feces. The eggs are ingested by the cockroaches, and incubated in their digestive system (Abrams et al. 2002).

The number of nematodes present in a bird's digestive system, the degree of the infestation, and how it is expressed clinically may vary dramatically. Oxyspiruriasis might be asymptomatic, or it may be limiting the bird's productive capacity and its overall well-being (Islam et al. 1995). Clinical signs include discomfort, ocular irritation, lacrimation, conjunctivitis, eye scratching, ophtalmia, keratitis, corneal opa- 


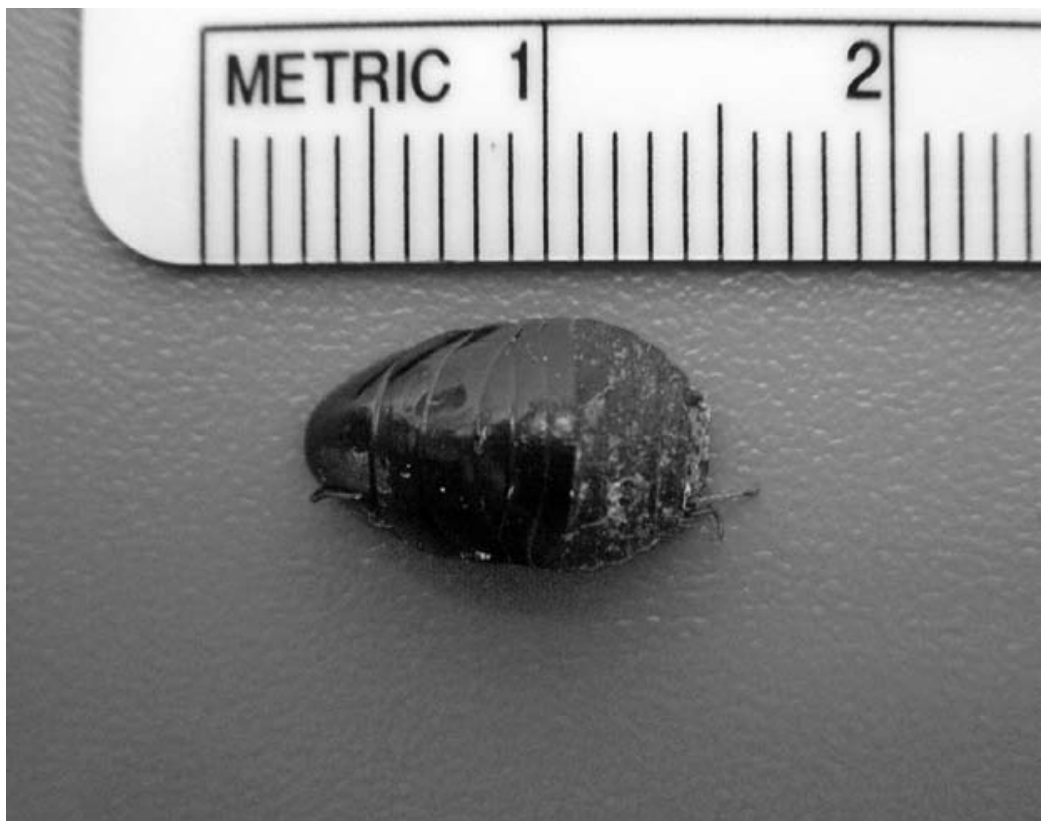

Figure 5. A nymph of Pycnoscelus surinamensis in which the characteristic bright abdominal segments, and opaque, rough posterior segments are depicted.

city, and inflammation of the nictitating membrane, which may protrude beyond the eyelids (Magalhaeset al. 2004). Occasionally, there is a watery discharge that might progress into obliteration of the eye due to palpebral adherence (Lee et al. 2006). In severe cases, the entire eyeball can be affected, the cornea thickens, and the eye cavity fills with exudate (Ranssom 1904). In the report presented herein, none of the clinical signs or lesions associated with the presence of $O$. mansoni was observed.

Upon physical examination and further necropsy, the clinical signs or pathological changes in the bird's eyes that can be associated with the presence of the parasite were not observed. This was possibly due to the reduced number of infective forms detected in this case. This is in agreement with previous reports where no evidence of ocular damage was observed in association with this parasite (Vellayan et al. 2012). This is likely one of the reasons why $O$. mansoni is easily undetected. Therefore, a meticulous evaluation of the eye and surrounding tissues is necessary when performing a necropsy (Magalhaes et al. 2004).

Ocular filariosis by $O$. mansoni has been reported in wild and free-roaming birds. However, it has not been reported to occur in birds reared in confinement. This is probably due to the progress made in the control of parasitic diseases of poultry reared under intensive commercial settings. Nevertheless, sanitary control is still deficient in 
backyard poultry flocks. In Mexico, there is a lack of information regarding the prevalence and pathological effects of $O$. mansoni in birds. In Monterrey, Nuevo Leon, there has also been a reported incident of $O$. mansoni in an owl kept in captivity for several months (Rodríguez-Tovar et al. 2008). In the report presented herein, a clinical case of $O$. mansoni in a free-range backyard hen was described. Furthermore, the intermediate host of the parasite was detected in the bird's living environment, and was identified as Pycnoscelus surinamensis. This finding provided additional aid to confirm the diagnosis. To the authors' knowledge, this is the first published report of $O$. mansoni in a domestic backyard hen. However, the two cases reported in Mexico were diagnosed in birds submitted to the laboratory due to non-specific clinical signs unrelated to this type of parasitoses. The prevalence of ocular filariosis by $O$. mansoni in domestic and wild birds, nonetheless, might be greater. Further studies are necessary to gain deeper knowledge about the biology, pathogenicity, and epidemiology of this parasitic disease in domestic free-range poultry reared in Mexico.

\section{LITERATURE CITED}

Abrams, G. A., Paul-Murphy, J. \& Murphy, C. J. 2002. Conjunctivitis in birds. Veterinary Clinic Exotic Animals, 5: 287-309.

Anderson, R. C. 2000. The nematode parasites of vertebrates: Their development and transmission. $2^{\text {nd }}$ edition. CABI Publishing, Wallingford, Oxon, UK, 672 pp.

Bermudez, A. J. \& Stewart-Brown, B. 2008. Principles of disease prevention: diagnosis and control, pp. 3-47. In: Y. M. Saif., A. M. Fadly, J. R. Glisson, L. R., Mc Dougald, L. K. Nolan, \& D. E. Swayne (Eds.). Diseases of Poultry. $12^{\text {th }}$ edition. Blackwell Publishing, Ames, Iowa.

Chirinos, R. A. R. \& Godoy, M. 1999. Oxyspirura mansoni (Spirurida: Thelaziidae) in fighting cocks of Trujillo State. Revista Científica FCV-LUZ, 9: 485-488.

De Chirinos, N. M., Chirinos, A. R., Briceño, J. \& Molina, M. 2009. New Focal Infection of Oxyspirura mansoni in gamecock of municipalities of Zulia State, Venezuela. Revista Cientifica FCVLUZ, 19:264-267.

Doster, G. L. \& Goater, C. P. 1997. Collection and quantification of avian helminths and protozoa, pp. 396-418. In: D.H. Clayton \& J. Mooru (Eds.). Host-parasite evolution. Oxford University Press, New York.

Islam, R. Z., Rahman, M. H.\&Mondal, M. M. H. 1995. Occurrence of eyeworm Oxyspirura mansoni (Cobbold, 1878) infection in chickens of Bangladesh. Bangladesh Veterinary Journal, 29: 67-70.

Jacobs, R. D., Hogsette, J. A. \& Butcher, G. D. 1997. Eye worms. Nematode parasites of poultry. Universidad de Florida, IFAS Extensión, Florida, 3 pp.

Lee, E. A., Irving, A. C. \& Pomproy, W. E. 2006. Oxyspirura sp. in the eye of a New Zealand Kaka (Necator meridionalis). New Zealand Journal of Zoology, 28: 227-231.

Magalhaes, P. R., Caldas, R. M. \& Corrêa, G. D. 2004. First report of five nematode species in Phasianus colchicus Linnaeus (Aves, Galliformes, Phasianidae) in Brazil. Revista Brasileira de Zoologia, 21: 961-970.

Ransom, B. H. 1904. Manson's eye worm of chickens: with a general review of nematodes parasitic in the eyes of birds. U.S. Department of Agriculture. Bureau Animal Industry Bulletin No. 60. Government Printing Office, Washington, 78 pp. 
Rodríguez-Tovar, L. E., Casas-Martínez, A., Ramírez-Romero, R., Nevárez-Garza, A. M. \& Zárate-Ramos, J. J. 2008. First report of Oxyspirura sp. in a captived Fulvous owl (Strisfulvescens) in Mexico. Journal of Parasitology, 94: 1430-1431.

Schwabe, C. W. 1950. Studies on Oxyspirura mansoni, the tropical eyeworm of poultry. III. Preliminay observations on eyeworm pathogenicity. American Journal of Veterinary Research, 11: 286-290.

Soulsby, E. 1983. Helminths, artropods and protozoa of domesticated animals. $7^{\text {th }}$ edition. Lea \& Febiger, Philadelphia, 809 pp.

Vellayan, S., Jeffery, J., Oothuman, P., Zahedi, M., Krishnasamy, M., Paramaswaran, S., Rohela, M. \& Abdul-Aziz, N. M. 2012. Oxyspiruriasis in zoo birds. Tropical Biomedicine, 29: 304-307.

Yazwinsk, T. A. \& Tucker, C. A. 2008. Nematodes and acanthocephalans, pp. 1025-1056. In: Y. M. Saif, A. M. Fadly, J. R. Glisson, L. R. Mc Dougald, L. K. Nolan, \& D. E. Swayne (Eds.). Diseases of Poultry. $12^{\text {th }}$ edition. Blackwell Publishing, Ames, Iowa. 